\title{
Study of Intellectual Capital on Drugs and Pharmaceutical Industry of India: Using Panel Data Analysis
}

S. Singhal ${ }^{a} \bowtie$, S. Guptab ${ }^{b}$ V.K Guptac

a, b Amity University, Noida, Noida, Uttar Pradesh, India; c Indian Institute of Management, Indore, Madhya Pradesh, India

$凶$ Corresponding author

\begin{abstract}
Intellectual capital is becoming increasingly important in financial decisions made by managers in the information-based environment. However, only a small portion of a company's total assets is represented by intangible assets (such as concessions, licenses, patents, and trademarks). The current research investigates the relationship between an organization's Intellectual capital and its health. A new model - Modified Extended Value-added Intellectual Capital Coefficient - was also proposed. The findings were compared with the two existing models, namely, Value Added Intellectual Coefficient and Modified Value Added Intellectual Coefficient. Panel data regression is used to assess the performance of 25 Indian pharmaceutical and drug companies throughout the period 2010-2019. Human capital efficiency, structural capital efficiency, and relational capital efficiency have been proven to have a substantial positive correlation with return on assets (ROA). In addition, a negative yet significant link exists between organizational capital efficiency and a company's profitability. Under the Value Added Intellectual Coefficient, human capital and structural capital efficiency do not affect the market value to book value. The market value-to-book value, on the other hand, is positively impacted by capital employed efficiency.
\end{abstract}

Keywords: financial health; pharmaceutical sector; organizational capital efficiency; intellectual capital

For citation: Singhal S., Gupta S., Gupta V.K. Study of intellectual capital on drugs and pharmaceutical industry of India: Using panel data analysis. Finance: Theory and Practice. 2022;26(1):66-78. DOI: 10.26794/2587-5671-202226-1-66-78

ОРИГИНАЛЬНАЯ СТАТЬЯ

\section{Исследование интеллектуального капитала в фармацевтической промышленности Индии: использование анализа панельных данных}

\author{
С. Сингхал ${ }^{\mathrm{a}} \mathrm{\text {,C.Гупта }}$, В.К. Гуптас \\ а, ь Университет Амити, Нойда, Уттар-Прадеш, Индия; \\ ' Индийский институт менеджмента, Индор, Мадхья-Прадеш, Индия \\ $\bowtie$ Автор для корреспонденции
}

\begin{abstract}
АННОТАЦИЯ
Интеллектуальный капитал приобретает все большее значение в финансовых решениях, принимаемых менеджерами в условиях информационной среды. Однако лишь небольшая часть общих активов компании представлена нематериальными активами (такими как концессии, лицензии, патенты и торговые марки). В данном исследовании авторы изучают взаимосвязь между интеллектуальным капиталом организации и ее финансовым здоровьем. Предложена новая модель - модифицированный расширенный коэффициент интеллектуального капитала с добавленной стоимостью. Полученные результаты авторы сравнили с двумя существующими моделями, а именно, коэффициентом интеллектуального капитала с добавленной стоимостью и модифицированным коэффициентом интеллектуального капитала с добавленной стоимостью. Регрессия панельных данных использована для оценки эффективности деятельности 25 индийских фармацевтических компаний за период 2010-2019 гг. Доказано, что эффективность человеческого, структурного и реляционно-
\end{abstract}

(c) Singhal S., Gupta S., Gupta V.K., 2022 
го капитала имеет существенную положительную корреляцию с рентабельностью активов (ROA). Kроме того, существует отрицательная, но значимая связь между эффективностью организационного капитала и прибыльностью компании. Согласно интеллектуальному коэффициенту добавленной стоимости эффективность человеческого и структурного капитала не влияет на соотношение рыночной и балансовой стоимости. С другой стороны, на соотношение рыночной и балансовой стоимости положительно влияет эффективность используемого капитала.

Ключевые слова: финансовое здоровье; фармацевтический сектор; эффективность организационного капитала; интеллектуальный капитал

Для цитирования: Singhal S., Gupta S., Gupta V.K. Study of intellectual capital on drugs and pharmaceutical industry of India: Using panel data analysis. Финансы: теория и практика. 2022;26(1):66-78. DOI: 10.26794/2587-5671-202226-1-66-78

\section{INTRODUCTION}

The economy has evolved from physical assets to an information-based environment in recent years. The information-based economy focuses on the contributions, originality, capacity, relationships, database, and knowledge of human resources within the premises of an organization. Intellectual Capital (IC) adds value to the product and services by actively managing the intangible assets, thus impacting the organization's health. Hence, tangible and intangible assets are essential sources for the growth of an organization. However, the relevance of IC is increasing day by day, but the disclosure of IC is limited in financial statements [1]. This is because the International Financial Reporting Standards (IFRS, 138) restricted the reporting of intangible assets, excluding goodwill in the financial statements [2]. Moreover, there is no proper framework for reporting IC [3]. Also, the reporting and disclosure of IC are in infancy in India [4]. Moreover, the quality of the human resource is still a concern in developing nations as regular training, skills, knowledge needs to be imparted to the employees. Because of this, the Indian Government, under the Ministry of Skill Development and Entrepreneurship (2015) scheme, has recognized the growth of intellectual assets, human capital, and innovation.

A well-managed IC will boost the organization's worth and skill in the financial market. Furthermore, the ongoing expansion of science and technology has made IC ideal for knowledge innovation. However, the management is inconsistent in reporting IC because of divergent results. The inconclusive results attribute no defined methodology to be used in developed or developing nations to calculate IC. Though many studies have used the Pulic model, the calculation of Structural Capital (SC) has been criticized. P. Ståhle, S. Ståhle, S. Aho [5] criticized the estimation of SC based on the Organization's Learning theory. The theory emphasizes a firm's capabilities, acquiring new knowledge and converting them into distinct methods, models, and copyrights. As a result, the studies have modified the calculation of SC. Our analysis also tried to fill this gap by introducing a new calculation measure for SC and renaming the variable organization capital (OC).

The present study examines Intellectual Capital Efficiency's impact on 25 Drugs and Pharmaceutical Industry's financial performance during 2010-2019. Also, the paper compares the new model Modified Extended Value-added Intellectual Capital coefficient (MEVAIC $^{\mathrm{TM}}$ ) with the existing two models, namely, Value-Added Intellectual Coefficient (VAIC ${ }^{\mathrm{TM}}$ ) and Modified Value-Added Intellectual Coefficient $\left(\right.$ MVAIC $\left.^{\mathrm{TM}}\right)$.

The paper has considered the pharmaceutical sector for three reasons. Primarily, it is a prominent sector in investing in intellectual property and Research and Development activities. Secondly, this sector induces high investment in IC and can face worldwide competition because of R\&D's experts, leading to new drugs, innovation, and patents [6]. Therefore, this sector is the best to examine different frameworks. Finally, the pharmaceutical industry is contemplated innovative and research-focused due to Human Capital, R\&D activities, the innovation of process or product, and intellectual dealing [7]. Therefore, our findings will help determine the appropriate framework for measuring IC's Drugs and Pharmaceutical industry performance.

This research adds to the existing literature in many ways. Firstly, a new variable, Organization Capital efficiency (OCE), has been introduced to see its impact on Financial Performance (FP). Secondly, this study has introduced a new model, MEVAIC, to conduct the empirical test and reveal robust results. Thirdly, the findings suggest that IC adds to the value of a company. Hence, it is essential to study 
the impact of intellectual capital on Indian Firms. Fourthly, it will be beneficial for the management in the measurement of IC.

The research draws up the subsequent sections. Section 2 focuses on the extent of literature and formulation of research questions. Section 3 discloses the research procedure and describes the variables used in the research. The fourth section discusses the study's result and finding, succeeded by the conclusion, limitations, and implications in section five.

\section{LITERATURE REVIEW}

It was in the 1990s when the term 'intellectual capital' gained attraction. Intangible assets are a form of intellectual capital, which are non-physical sources of value derived from novelty, structural goals, or human resources. The researchers define IC as an intangible value creation component [8]. As a result, IC has three components: human, structural, and relational or customer capital. The first and foremost component is Human Capital (HC), defined as employees' experience, ability, skills, attitude, morals, and capabilities [9]. It can be enhanced by providing training to the employees. This investment in training and development will create both tangible and intangible assets for the organization. The second component is Structural Capital (SC), which means "the set of knowledge and intangible assets derived from the processes of action owned by the organization and that remain in it when people leave". In other words, it is knowledge created by enterprises that cannot be separated from the entity. Patents, discoveries, progress, copyright, know-how, and systems all appends to SC. The third component is Relational Capital (RC) that refers to an organization's external relationships with the government, suppliers, consumers, and stockholders [10]. This capital is an organization's ability to create value with external investors. With a good market reputation, goodwill, customer satisfaction, strategic alliances, enterprises can expand significantly.

\subsection{Model VAICTM}

A. Pulic [11] has developed the model of VAIC ${ }^{\text {тM }}$ to measure the efficiency of crucial resources. It is the most widely used research model due to its simplicity [12] and cross-sectional comparisons [13] and to examine the relation between IC and FP. In addition, the VAIC ${ }^{\mathrm{TM}}$ method is objective as it doesn't require any grading, judgment, or weightage [14]. This model is prevalent because of audited data availability [2].

\subsection{Research gap}

Despite having so many advantages, it has been criticized by a few. D. Maditinos, D. Chatzoudes, C. Tsairidis et al. [12] have challenged the VAIC model in terms of its reliability. They have stated that this model neglects its negative book value, resulting in reduced output value compared to input values. P. Ståhle, S. Ståhle, S. Aho [5] criticize this model for theoretical inconsistencies, excluding external capital and calculation of SC. Several attempts have been made to modify the SC calculations, and new models have been introduced $[2,7]$. The present study is also an attempt to address the criticism. Previous studies have treated $\mathrm{R} \& \mathrm{D}$ as $\mathrm{SC}$ but have also changed the calculation of SCE. This study only changes SC's parameter, but the calculation method of SCE is the same as proposed by A. Pulic [11]. We have also replaced the old SCE measure with the OCE measure to understand the models better.

\subsection{Prior Studies}

The pharmaceutical and medication sector has undertaken numerous studies all around the world. According to certain research, IC has a substantial impact on an organization's performance [15]. Tangible assets or physical capital have been suggested in certain studies to be important to firm success [16-18].

A study [19] on top 200 listed companies from 2010-2015 used the VAIC ${ }^{\mathrm{TM}}$ model to estimate IC's impact using Ordinary Least Squares (OLS). It was found that firm performance differs in firms with or without government. Also, CEE, HCE, and ICE significantly impact performance, whereas SCE was insignificant. S. Aslam, S. Amin [20] also used the VAIC $^{\text {TM }}$ model, and the study revealed that IC has a positive effect on the firms' financial performance.

Z. Xinyu [21] researched in China during 20002001 to $2009-2010$ using the VAIC ${ }^{\text {TM }}$ model and concluded that HC and CE impact IC but SC does not have any effect. The study by K. Tandon, H. Purohit, D. Tandon [22] concluded that HCE and CEE positively impact profitability and market valuation, but SCE failed to show any impact on corporate performance. I. M. Nazir, Y. Tan, M. R. Nazir [10] applied system GMM to examine the relationship of IC on FP. The results show the positive association of IC with FP. The research was conducted in Australia on 571 firms for the period 2005-2014. 
From the literature mentioned above, there are mixed results. The most widely used method is VAIC $^{\text {TM, }}$ with dual components. Different researchers are exploring various components in their framework and trying to study the effect.

This paper aims to estimate the value of IC of Drugs and Pharmaceutical industries in India and study its impact on the FP. The VAIC ${ }^{\mathrm{TM}}$ model is the base model. However, this model only examines HC and SC. Many researchers [7, 23, 24] modified this model using new components: RC, process capital, and innovation capital. The second model used for the comparison is MVAIC ${ }^{\mathrm{TM}}$, which uses RC as an additional component. The third model proposed in this study is MEVAIC ${ }^{\mathrm{TM}}$.

This is a unique study as no previous research has been conducted to examine the different frameworks. This study tries to answer two research questions

RQ1: How do the components of IC impact the FP of an organization?

RQ2: How do the components of IC impact the market performance of an organization?

\section{RESEARCH METHODOLOGY}

To analyze the effectiveness of the three models, the drugs and pharmaceutical sector has been considered. Information-based resources impact the industry, making it an excellent place to look at the components of IC [25]. The sample, data, models, and variables utilized in the study are discussed in this section.

\subsection{Sample and Data}

This study's data was sourced from the Capitaline Database, a secondary source. The sample comprises 25 pharmaceutical companies in India. The selected companies are listed under the Bombay stock exchange (BSE-500). Initially, there were 36 firms; 11 were dropped because of negative Value Added (VA). According to VAIC ${ }^{\mathrm{TM}}$, the model does not apply to businesses that have more input than output. The information of the variables was readily available in the database. The data values missing in the data have been manually filled from Annual Reports. The data has been collected for a decade study from 2010-2019. Thus, the final sample size was 25 firms for ten years, owing to 260 observations. The data is processed in Stata 14 to examine the relationship among the variables.

\subsection{Variables}

3.2.1. Predicted Variables - This study includes two important predicted variables to measure the firms' performance in various research [26, 27]. Return on assets (ROA) is employed as the profitability indicator and market-to-book value (MB) indicator for the Market Performance. The measured variable has been elucidated below:

a. ROA is calculated by dividing operating income by total assets [4].

b. MB is computed by dividing Market Capitalisation with Shareholder's equity [6].

3.2.2. Control variables - Studies have used control variables for firm size, industry, and leverage to study IC's impact on an organization's performance $[28,29]$. However, this study has not introduced any control variable in the regression equation as the sectors are the same and can be compared [7].

3.2.3. Explanatory Variable - The study employs five explanatory variables

a. HC Efficiency (HCE)

b. SC Efficiency (SCE)

c. RC Efficiency (RCE)

d. OC Efficiency (OCE)

e. Capital Employed Efficiency (CEE)

Before proceeding to the analysis, the details about the three models are mentioned below:

1. The VAIC ${ }^{T M}$ Model:

A. Pulic [11] suggested the model of VAIC ${ }^{\text {TM }}$ measure IC. This model conceptualizes Value Added (VA) as a measure to calculate the Intellectual Capital Efficiency (ICE). Many studies have considered the VAIC $^{\mathrm{TM}}$ model to analyze the impact of IC on a firm's performance $[4,7,26]$. However, the calculation of VAIC involves specific steps.

Step 1: Calculation of VA

$$
V A=O U T-I N,
$$

Where,

OUT - Output, which is calculated with the help of total sales or total revenues

IN - Input, which is the cost of materials, services, and components

In other words, VA can also be expressed as:

$$
V A=O P+E C+D+A \text {. }
$$

OP represents the Operating Profit, EC is the Employee Cost, D stands for the depreciation, and A is Amortization.

Step 2: Calculation of the efficiency of HC, SC, and capital employed (CE).

2.1. Calculation of HCE

$$
H C E=\frac{V A}{H C} .
$$

Here, HC is the proxy for Wages and Salaries. 
2.2. Second Component is SCE and is calculated as follows:

$$
S C E=\frac{S C}{V A} .
$$

Here, SC is the difference between VA and HC.

So, as per A. Pulic [11], ICE is the total of the coefficients of HCE and SCE.

$$
I C E=H C E+S C E .
$$

A. Pulic [30] stated that to know the true and fair image of the resources creating value in the organization, it is necessary to consider inputs production function.

2.3. Calculation of CEE

$$
C E E=\frac{V A}{C E} .
$$

Where CE is the book value of net assets of the company.

Step 3: Calculation of Value-Creating Efficiency, which is the total of all the efficiency Coefficients.

$$
V A I C=I C E+C E E
$$

OR

$$
V A I C=H C E+S C E+C E E
$$

OR

$$
V A I C=\left(\frac{V A}{H C}\right)+\left(\frac{S C}{V A}\right)+\left(\frac{V A}{C E}\right) .
$$

\section{The MVAIC ${ }^{\mathrm{TM}}$ Model:}

N. Bontis [23] suggested The MVAIC ${ }^{T M}$ framework estimates ICE on the FP. The VAIC ${ }^{\text {TM }}$ Model framework used the coefficients of three sub-components HCE, SCE, and CEE. The MVAIC ${ }^{\mathrm{TM}}$ Model calculates the RCE coefficient $[23,31,32]$ along with the other three sub-components. The RCE is computed as follows:

$$
R C E=\frac{R C}{V A} .
$$

Here RC is relational Capital, which denotes advertisement, marketing, and selling and distribution expenditure. It is assumed that such costs are incurred to build and sustain relationships with external stakeholders [7].

$$
M V A I C T M=H C E+S C E+R C E+C E E .
$$

\section{The MEVAIC ${ }^{T M}$ Model:}

In this model, the measurement criterion for SC is different from the base model. The proxy to calculate
SC is through R\&D expenditure [7]. According to the VAIC model, SC is the difference between value added and employee cost. This means that SC is the total operating profit, depreciation, and amortization, which is incorrect as per the organization's learning theory [5]. Because of this issue, different researchers have tried to overcome this issue by introducing a modified version of VAIC. J.A. Nazari, I. M. Herremans, R. G. Issac et al. [33] divided the component into customer, innovation, and process capital. S. Vishnu, V.K. Gupta [7] proposed three new models with two new proxy measures. The new measures were $\mathrm{RC}$ that was calculated using selling and marketing expenses. Also, the SC measurement was changed to $R \& D$ expenses instead of the difference between VA and HC. However, the author didn't change the base model; instead, it introduced three different models. In the first model, VA was used in the numerator to measure the efficiencies of all the components. In the second model, Net Sales were used instead of VA to calculate the coefficients of components of IC. In the third model, intensities were calculated using net sales in the denominator. The Adjusted VAIC model has been proposed by M. Nadeem, C. Gan, C. Nguyen [34], where SC is calculated using $R \& D$ expenses and copyrights investment. Also, M. Nadeem, C. Gan, C. Nguyen [34] have renamed SC as Innovation capital (INVC). No study has changed SC's calculation without any other change in the MVAIC ${ }^{\mathrm{TM}}$ model. This model is similar to MVAIC ${ }^{\mathrm{TM}}$, except the calculation of SC has changed. The SC has been renamed OC for ease of understanding.

$$
O C E=\frac{O C}{V A} .
$$

Where $O C=R \& D$ expenses and OCE is Organizational Capital Efficiency. So,

$$
\begin{aligned}
& M E V A I C T M=H C E+O C E+R C E+C E E \\
& M E V A I C=\left(\frac{V A}{H C}\right)+\left(\frac{O C}{V A}\right)+\left(\frac{V A}{R C}\right)+\left(\frac{V A}{C E}\right) .
\end{aligned}
$$

The details about the models can be witnessed in Fig. 1 and Fig. 2.

\section{FINDINGS AND DISCUSSION 4.1. Regression Equations}

Numerous researchers have applied OLS regression to estimate the impact of IC on business profitability, which has the problem of not accounting for variation across time or groups [35]. The research has used a panel data regression 


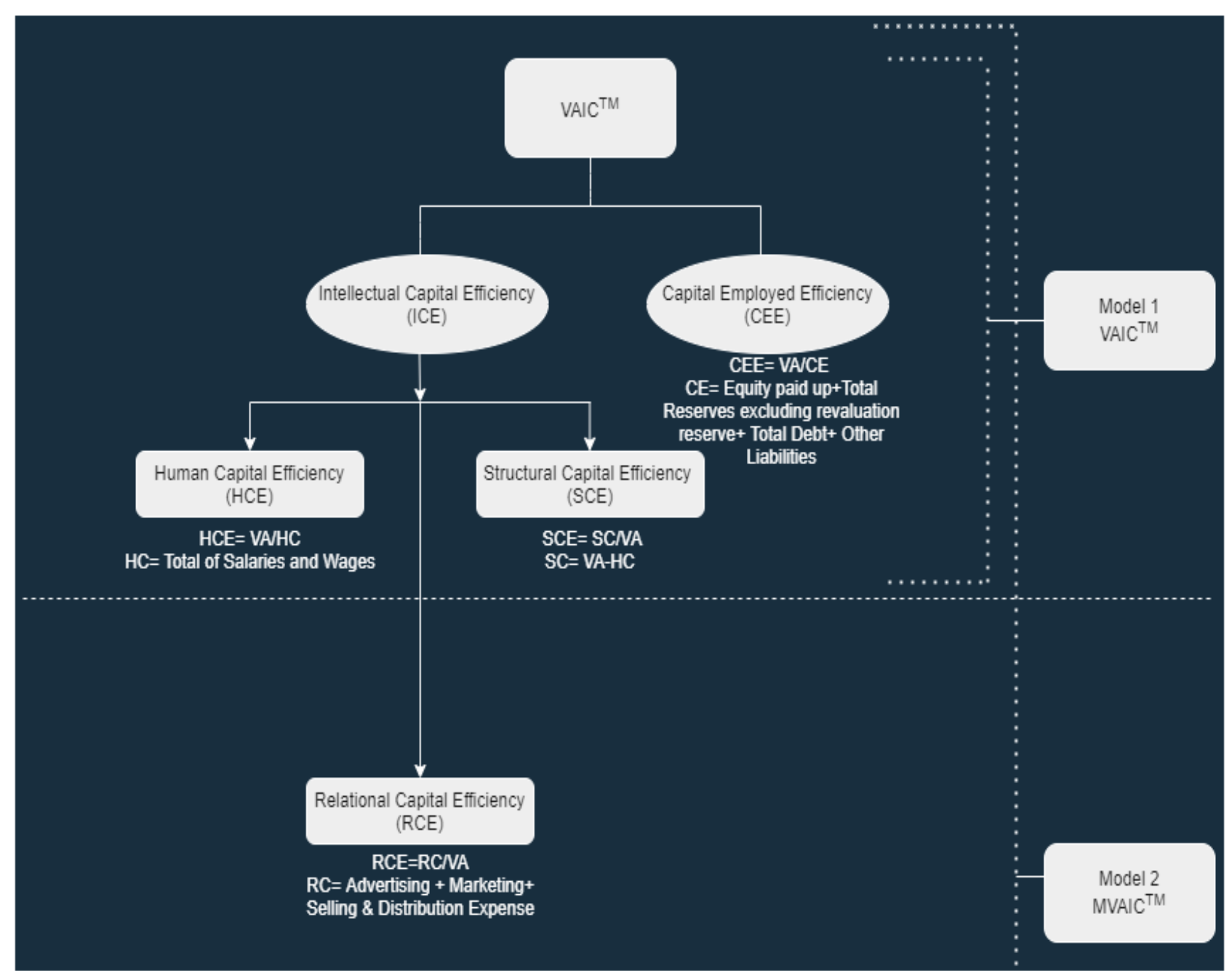

Fig. 1. Model 1: VAIC and Model 2: MVAIC

Source: compiled by the author.

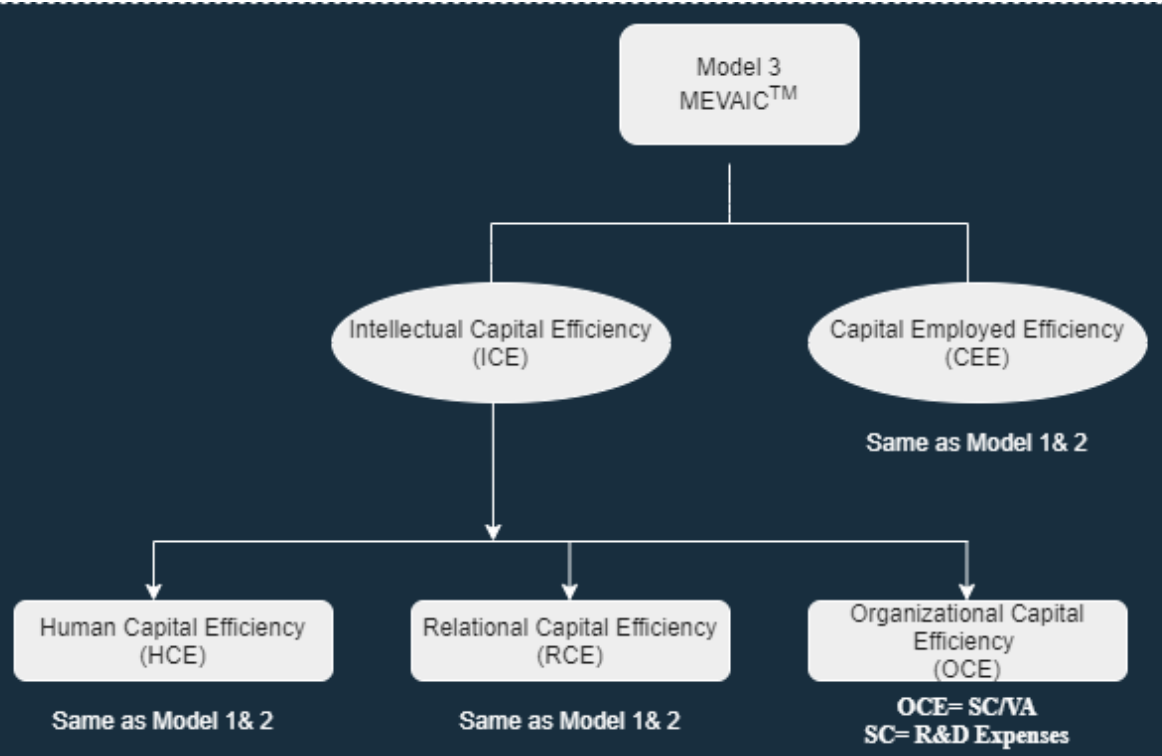

Fig. 2. Model 3 - MEVAIC

Source: compiled by the author. 


\section{Descriptive Statistics}

\begin{tabular}{|l|c|c|c|c|c|}
\hline \multicolumn{1}{|c|}{ Variable } & Mean & Std. Dev. & Min & Max & Observations \\
\hline HCE & 12.785 & 7.928 & 5.996 & 80.982 & $N=250$ \\
\hline SCE & 0.907 & 0.032 & 0.833 & 0.988 & $N=250$ \\
\hline OCE & 0.052 & 0.044 & 0.000 & 0.243 & $N=250$ \\
\hline RCE & 0.054 & 0.033 & 0.001 & 0.171 & $N=250$ \\
\hline CEE & 0.950 & 0.349 & 0.085 & 2.047 & $N=250$ \\
\hline VAICTM & 14.642 & 8.033 & 7.570 & 83.229 & $N=250$ \\
\hline MVAICTM & 14.695 & 8.027 & 7.574 & 83.261 & $N=250$ \\
\hline MEVAICTM & 13.840 & 7.993 & 6.740 & 82.274 & $N=250$ \\
\hline ROA & 0.821 & 0.314 & 0.068 & 1.742 & $N=250$ \\
\hline MB & 4.604 & 4.752 & 0.000 & 40.554 & $N=250$ \\
\hline
\end{tabular}

Source: compiled by the author.

Table 2

\section{Correlation Matrix}

\begin{tabular}{|c|c|c|c|c|c|}
\hline Variables & HCE & SCE & OCE & RCE & CEE \\
\hline HCE & 1.000 & & & & \\
\hline SCE & $0.7597^{* *}$ & 1.000 & & & \\
\hline OCE & $-0.2214^{* *}$ & -0.1201 & 1.000 & & \\
\hline RCE & $-0.1698^{* *}$ & $-0.2445^{* *}$ & 0.0532 & 1.000 & \\
\hline CEE & $0.2102^{* *}$ & $0.1529^{*}$ & $-0.2065^{* *}$ & $0.185^{* *}$ & 1.000 \\
\hline
\end{tabular}

Source: compiled by the author.

model to overcome this problem. Nine regression equations across three models have been tested to assess the impact of IC on financial health. The equations are as follows:

Model 1: VAIC ${ }^{\text {TM }}$

$Y_{i t}=\alpha+\beta_{1}\left(H C E_{i t}\right)+\beta_{2}\left(S C E_{i t}\right)+\beta_{3}\left(C E E_{i t}\right)+\varepsilon_{i t}$.

Model 2: MVAIC ${ }^{\mathrm{TM}}$

$$
\begin{gathered}
Y_{i t}=\alpha+\beta_{1}\left(H C E_{i t}\right)+\beta_{2}\left(S C E_{i t}\right)+ \\
+\beta_{3}\left(R C E_{i t}\right)+\beta_{4}\left(C E E_{i t}\right)+\varepsilon_{i t}
\end{gathered} .
$$

Model 3: MEVAIC ${ }^{\mathrm{TM}}$

$$
\begin{gathered}
Y_{i t}=\alpha+\beta_{1}\left(H C E_{i t}\right)+\beta_{2}\left(O C E_{i t}\right)+ \\
+\beta_{3}\left(R C E_{i t}\right)+\beta_{4}\left(C E E_{i t}\right)+\varepsilon_{i t} .
\end{gathered}
$$

Where $\mathrm{Y}$ is the predicted variable, $\alpha$ is the constant, $\beta$ is the regressor's coefficient, and $\varepsilon$ is the error term for cross-section $i$ at time $t$, respectively.

The panel data regression can either be Fixed Effect (FE) or Random Effect (RE). To determine the suitable regression model, the Hausman specification test by M. Arellano [36] is applied [37].

\subsection{Results}

\subsubsection{Descriptive Statistics}

The summary of the variables for all three models has been presented in Table 1. It can be observed from Table 1 the mean value of HCE is the maximum (80.982) of Bliss GVS Pharma, and the minimum value of HCE (5.996) is Syngene International Limited. This represents that Bliss GVS Pharma spends less on its employee in comparison to Sygene International Limited. Also, the mean value of HCE is maximum 
than SCE, RCE, and OCE. Therefore, the study is in line with $[38,39]$. The total of intangible assets (HCE, RCE, SCE, OCE) is more than CEE, which means that companies concentrate more on intangibles than tangibles. Of the three models used in this study, the standard deviation of MEVAIC ${ }^{\mathrm{TM}}$ (7.993) is less in comparison to VAIC ${ }^{\mathrm{TM}}$ (8.033) and MVAIC $^{\mathrm{TM}}$ (8.027). This means that the data for MEVAIC ${ }^{\mathrm{TM}}$ is more clustered in contrast to the other two models.

\subsubsection{Correlation}

The correlation graph is displayed in Table 2 between the explanatory variables of all three models. It can be observed that no explanatory variable is strongly correlated with other variables. Therefore, there is no multicollinearity problem as no variable in the correlation matrix has a coefficient more than 0.8 [40]. Apart from this Variance Inflation Factor (VIF) is calculated to test the issue of multicollinearity. Table 3 shows the values of VIF. The highest value of VIF is 2.5, which suggests that multicollinearity is not present in the data as VIF values are less than 10 and the tolerance level is above 0.10 [41, 42].

\subsubsection{Diagnostic Test}

Before applying the panel regression, the following diagnostic tests were used:

1. Stationarity - The Levin, Lin, and Chu unit root test was used to determine stationarity. As the $\mathrm{p}$-value is less than 0.05 , the alternate hypothesis is accepted. This means there is no unit root or stationary in the data.

2. Multicollinearity - From Table 3, it can be witnessed that VIF is 2.5 , which is less than 10 , and tolerance level above 0.10 [41].

3. Heteroscedasticity - Breusch-Pagan test was applied to test the heteroscedasticity, and the results depicted that the p-value is less than $0.5 \%$, thus rejecting the null hypothesis. Hence, there is the problem of Heteroskedasticity.

4. Serial Autocorrelation - The Wooldridge serial correlation diagnostic test was applied, and the results did not accept the null hypothesis. Thus, there was the problem of autocorrelation in the data.

Therefore, there was the problem of heteroscedasticity and autocorrelation in the data. For this, robust regression results are shown.

\subsubsection{Panel Regression Analysis}

The effect of IC on FP was examined using panel data regression analysis. Panel data regression can control companies' factors and report individual heterogeneity [15].

From Tables 4-6 the results could be inferred for panel data. When all the three models using a

\section{VIF and Tolerance Results to check Multicollinearity}

Table 3

\begin{tabular}{|l|c|c|}
\hline \multicolumn{1}{|c|}{ Variable } & VIF & 1/VIF \\
\hline HCE & 2.5 & 0.40054 \\
\hline SCE & 2.47 & 0.40557 \\
\hline CEE & 1.14 & 0.87562 \\
\hline RCE & 1.13 & 0.8849 \\
\hline OCE & 1.09 & 0.91417 \\
\hline Mean & VIF & 1.67 \\
\hline
\end{tabular}

Source: compiled by the author.

regression for ROA are considered, $\mathrm{R}^{2}$ in all the three models is very high, and there is not much difference between the values of $\mathrm{R}^{2}$. All the components IC, HCE, SCE, CEE, RCE, and OCE impact the traditional measure of Firm Performance. The newly introduced component, OCE, also has a negative and significant effect on ROA. Of all the three models, Model 3, MEVAIC, has the highest F value of 23.96, which is substantial at a confidence interval of 95 percent. Our findings confirm that HCE impacts a company's performance; investing in employees should be considered an investment rather than a cost.

The last explained variable which has been used to study the market performance is MB. HCE and RCE are negative and significant efficiencies in the case of market performance. However, CEE is positively significant with MB. SCE and OCE have no impact on the market performance of an organization. When all the three models are considered, the best model to measure the Market Performance is Model 2: MVAIC ${ }^{\mathrm{TM}}$. It has the highest coefficient of determination and F Statistics value, 10.2 percent and 7.73, respectively. The panel data results reveal that the traditional VAIC model didn't give the best results amongst all three models. As under VAIC model, HCE and SCE do not affect the MB, however, MB is positively impacted by CEE.

It means that businesses should concentrate on improving staff abilities and sustaining relationships with stakeholders. Expenditures on information and networking, policies, and frameworks should also be managed effectively to reap the maximum benefits. In addition, the usual care should be devoted to financial capital at the same time. If these assets are appropriately used and managed consistently, they can produce more profitable results. As a result, the conclusion is that entire intellectual capital should 
Model 1 - VAICTM

Table 4

\begin{tabular}{|c|c|c|c|c|}
\hline \multirow{2}{*}{$\begin{array}{l}\text { Model } 1 \text { - VAIC } \\
\text { Variables }\end{array}$} & \multicolumn{2}{|c|}{ Model 1: ROA } & \multicolumn{2}{|c|}{ Model 2: MB } \\
\hline & $\begin{array}{c}\text { Fixed Effect } \\
\text { Coefficient (t-value) }\end{array}$ & $\begin{array}{c}\text { Random Effect } \\
\text { Coefficient (z-value) }\end{array}$ & $\begin{array}{l}\text { Fixed Effect Coefficient } \\
\text { (t-value) }\end{array}$ & $\begin{array}{c}\text { Random Effect } \\
\text { Coefficient (z-value) }\end{array}$ \\
\hline Constant & $-0.75(-13.22)^{*}$ & $-0.841(-15.58)^{*}$ & $2.77(0.32)$ & $0.181(0.02)$ \\
\hline $\mathrm{HCE}$ & $0.001(4.11)^{*}$ & $0.001(4.17)^{*}$ & $-0.064(-1.88)$ & $-0.062(-1.88)$ \\
\hline SCE & $0.799(12.2)^{*}$ & $0.903(14.56)^{*}$ & $-0.408(-0.04)$ & $2.993(0.34)$ \\
\hline CEE & $0.879(186.32)^{*}$ & $0.875(200.81)^{*}$ & $2.543(3.59)^{*}$ & $1.989(3.22)^{*}$ \\
\hline R square (Within) & 0.996 & 0.9954 & 0.0613 & 0.0605 \\
\hline Rho & 0.647 & 0.479 & 0.443 & 0.403 \\
\hline Hausman Test & \multicolumn{2}{|c|}{$\chi^{2}=193.73$, Prob $>\chi^{2}=0.0000$} & \multicolumn{2}{|c|}{$\chi^{2}=143.82$, Prob $>\chi^{2}=0.0000$} \\
\hline $\begin{array}{l}\text { Model } \\
\text { appropriate }\end{array}$ & \multicolumn{2}{|c|}{ Fixed Effect Model } & \multicolumn{2}{|c|}{ Fixed Effect Model } \\
\hline $\begin{array}{l}\text { F- Statistics/ } \\
\text { Wald }\end{array}$ & 11.66 & $\chi 2=52958.6$ & 7.16 & $\chi^{2}=12.22$ \\
\hline Chi-square & Prob $>F=0.0000$ & Prob $>\chi^{2}=0.000$ & Prob $>F=0.0000$ & Prob $>\chi^{2}=0.0067$ \\
\hline
\end{tabular}

Source: compiled by the author.

Table 5

\section{Model 2 - MVAIC $^{\mathrm{TM}}$}

\begin{tabular}{|c|c|c|c|c|}
\hline \multirow{2}{*}{$\begin{array}{l}\text { Model } 2 \text { - MVAIC } \\
\text { Variables }\end{array}$} & \multicolumn{2}{|c|}{ Model 1: ROA } & \multicolumn{2}{|c|}{ Model 2: MB } \\
\hline & $\begin{array}{c}\text { Fixed Effect } \\
\text { Coefficient (t-value) }\end{array}$ & $\begin{array}{c}\text { Random Effect } \\
\text { Coefficient (z-value) }\end{array}$ & $\begin{array}{c}\text { Fixed Effect } \\
\text { Coefficient (t-value) }\end{array}$ & $\begin{array}{c}\text { Random Effect } \\
\text { Coefficient (z-value) }\end{array}$ \\
\hline Constant & $-0.751(-13.35)^{*}$ & $\begin{array}{c}-0.877 \\
(-16.36)^{*}\end{array}$ & $\begin{array}{l}2.931 \\
(0.35)\end{array}$ & $\begin{array}{l}2.128 \\
(0.28)\end{array}$ \\
\hline HCE & $\begin{array}{c}0.001 \\
(4.28)^{*}\end{array}$ & $\begin{array}{l}0.001 \\
(4.27)^{*}\end{array}$ & $\begin{array}{l}-0.070 \\
(-2.12)^{*}\end{array}$ & $\begin{array}{l}-0.066 \\
(-2.06)^{*}\end{array}$ \\
\hline SCE & $\begin{array}{c}0.794 \\
(12.23)^{*}\end{array}$ & $\begin{array}{c}0.939 \\
(15.28)^{*}\end{array}$ & $\begin{array}{l}0.631 \\
(0.07)\end{array}$ & $\begin{array}{l}1.636 \\
(0.19)\end{array}$ \\
\hline RCE & $\begin{array}{c}0.131 \\
(2.19)^{*}\end{array}$ & $\begin{array}{c}0.125 \\
(2.42) *\end{array}$ & $\begin{array}{l}-28.188 \\
(-3.16)^{*}\end{array}$ & $\begin{array}{l}-20.587 \\
(-2.76)^{*}\end{array}$ \\
\hline CEE & $\begin{array}{c}0.876 \\
(182.4)^{*}\end{array}$ & $\begin{array}{c}0.870 \\
(197.32) *\end{array}$ & $\begin{array}{c}3.060 \\
(4.29) *\end{array}$ & $\begin{array}{l}2.463 \\
(3.89) *\end{array}$ \\
\hline R square (Within) & 0.996 & 0.996 & 0.102 & 0.101 \\
\hline Rho & 0.651 & 0.392 & 0.485 & 0.427 \\
\hline Hausman Test & \multicolumn{2}{|c|}{$\begin{array}{c}\chi^{2}=128.1 \\
\text { Prob }>\chi^{2}=0.0000\end{array}$} & \multicolumn{2}{|c|}{$\begin{array}{c}\chi^{2}=150.15 \\
\text { Prob }>\chi^{2}=0.0000\end{array}$} \\
\hline Model appropriate & \multicolumn{2}{|c|}{ Fixed Effect Model } & \multicolumn{2}{|c|}{ Fixed Effect Model } \\
\hline F- Statistics/Wald & 10.28 & $\chi^{2}=53887.66$ & 7.73 & $\chi^{2}=20.40$ \\
\hline Chi-square & Prob $>F=0.0000$ & Prob $>\chi^{2}=0.000$ & Prob $>F=0.000$ & Prob $>\chi^{2}=0.0004$ \\
\hline
\end{tabular}

Source: compiled by the author. 
Model 3 - MEVAIC ${ }^{\text {TM }}$

Table 6

\begin{tabular}{|c|c|c|c|c|}
\hline $\begin{array}{l}\text { Model } 3 \text { - } \\
\text { MEVAIC }\end{array}$ & \multicolumn{2}{|c|}{ Model 1: ROA } & \multicolumn{2}{|c|}{ Model 3: MB } \\
\hline Variables & $\begin{array}{c}\text { Fixed Effect } \\
\text { Coefficient (t-value) }\end{array}$ & $\begin{array}{c}\text { Random Effect } \\
\text { Coefficient (z-value) }\end{array}$ & $\begin{array}{c}\text { Fixed Effect } \\
\text { Coefficient (t-value) }\end{array}$ & $\begin{array}{c}\text { Random Effect } \\
\text { Coefficient (z-value) }\end{array}$ \\
\hline Constant & $\begin{array}{l}-0.054 \\
(-7.59)^{*}\end{array}$ & $\begin{array}{l}-0.053 \\
(-6.1)^{*}\end{array}$ & $\begin{array}{l}3.161 \\
(3.81)^{*}\end{array}$ & $\begin{array}{l}2.787 \\
(3.48)\end{array}$ \\
\hline HCE & $\begin{array}{l}0.002 \\
(9.65)^{*}\end{array}$ & $\begin{array}{l}0.003 \\
(10.8)^{*}\end{array}$ & $\begin{array}{l}-0.068 \\
(-2.4)^{*}\end{array}$ & $\begin{array}{l}-0.056 \\
(-2.18)^{*}\end{array}$ \\
\hline OCE & $\begin{array}{l}-0.146 \\
(-2.91)^{*}\end{array}$ & $\begin{array}{l}-0.127 \\
(-2.59)\end{array}$ & $\begin{array}{l}4.045 \\
(0.69)\end{array}$ & $\begin{array}{l}10.238 \\
(2.03)^{*}\end{array}$ \\
\hline RCE & $\begin{array}{l}0.147 \\
(1.92)^{*}\end{array}$ & $\begin{array}{l}0.115 \\
(1.59)\end{array}$ & $\begin{array}{l}-27.897 \\
(-3.13)^{*}\end{array}$ & $\begin{array}{l}-19.152 \\
(-2.67)^{*}\end{array}$ \\
\hline CEE & $\begin{array}{c}0.889 \\
(148.71)^{*}\end{array}$ & $\begin{array}{c}0.886 \\
(150.69)^{*}\end{array}$ & $\begin{array}{l}3.153 \\
(4.52)^{*}\end{array}$ & $\begin{array}{l}2.551 \\
(4.14)^{*}\end{array}$ \\
\hline R square (Within) & 0.993 & 0.993 & 0.098 & 0.095 \\
\hline Rho & 0.780 & 0.670 & 0.468 & 0.350 \\
\hline Hausman Test & \multicolumn{2}{|c|}{$\begin{aligned} \chi^{2} & =356.18 \\
\text { Prob } & >\chi^{2}=0.0000\end{aligned}$} & \multicolumn{2}{|c|}{$\begin{aligned} \chi^{2} & =94.69 \\
\text { Prob }>\chi^{2} & =0.0000\end{aligned}$} \\
\hline Model appropriate & \multicolumn{2}{|c|}{ Fixed Effect Model } & \multicolumn{2}{|c|}{ Fixed Effect Model } \\
\hline $\begin{array}{l}\text { F- Statistics/ } \\
\text { Wald }\end{array}$ & 23.96 & $\chi^{2}=31137.94$ & 6.28 & $\chi^{2}=23.16$ \\
\hline Chi-square & Prob $>F=0.0000$ & Prob $>\chi^{2}=0.000$ & Prob $>F=0.000$ & Prob $>\chi^{2}=0.0001$ \\
\hline
\end{tabular}

Source: compiled by the author.

be considered to acquire a competitive edge and improve business financial performance.

\section{CONCLUSIONS}

Due to globalization and open competition, India's business environment has changed significantly, creating an array of new prospects. Businesses must focus on intangible asset productivity and efficiency and the growth of tangible asset value to thrive in a competitive climate. Because of this, IC is seen as a vital part of creating value for companies in a knowledge-based economy. In addition, IC elements can be shown to influence the organization's health.

From Fig. 2 change in the model could be seen, and panel data analysis of the same using the three models VAIC $^{\mathrm{TM}}$ [11], MVAIC ${ }^{\mathrm{TM}}$ [23], and MEVAIC $^{\mathrm{TM}}$ proposed in the current study can be observed from
Tables 4-6. It can be witnessed that MEVAIC ${ }^{\mathrm{TM}}$ is the best model for measuring ROA using panel data as the value of F-statistics is higher in Model 3. Investors, policymakers, shareholders, and regulators will benefit from the conclusions of this study. With this tool, executives can better understand regulating and enhancing their organization's IC while increasing their outlay on tangible resources. As a result of the findings, both investors and shareholders will be able to make better investment decisions and analyze the IC of companies to optimize financial rewards. In addition, the study provides valuable information for policymakers and regulators who want to examine a firm's IC efficiency and compare different industries to develop adequate rules for reporting intellectual capital. Businesses should effectively manage and invest in IC to maximize their profitability, according to the research findings. 
Despite the growing relevance of IC, only a few companies report on it or acknowledge it in their annual reports, and IC is still a relatively new concept in India.

The study suffers from its limitations. It has limited its research only to the pharmaceutical sector, which can be a future scope. The analysis can be applied to other industries, and the new proposed model can be verified for different sectors. Crosscountry comparisons can be prepared. Productivity can also be calculated, and other proxies to measure profitability can be employed.

\section{REFERENCES}

1. Wang Z., Wang N., Cao J., Ye X. The impact of intellectual capital - knowledge management strategy fit on firm performance. Management Decision. 2016;54(8):1861-1885. DOI: 10.1108/MD-06-2015-0231

2. Nadeem M., Dumay J.C., Massaro M. If you can measure it, you can manage it: A case of intellectual capital. Australian Accounting Review. 2018;29(2):395-407. DOI: 10.1111/auar.12227

3. Chiucchi M. S., Dumay J. Unlocking intellectual capital. Journal of Intellectual Capital. 2015;16(2):305330. DOI: 10.1108/JIC-01-2015-0004

4. Smriti N., Das N. The impact of intellectual capital on firm performance: A study of Indian firms listed in COSPI. Journal of Intellectual Capital. 2018;19(5):935-964. DOI: 10.1108/JIC-11-2017-0156

5. Ståhle P., Ståhle S., Aho S. Value added intellectual coefficient (VAIC): A critical analysis. Journal of Intellectual Capital. 2011;12(4):531-551. DOI: 10.1108/14691931111181715

6. Amin S., Aslam S. Intellectual capital, innovation and firm performance of pharmaceuticals: A study of the London Stock Exchange. Journal of Information \& Knowledge Management. 2017;16(2):1750017. DOI: 10.1142/S 0219649217500174

7. Vishnu S., Gupta K.V. Intellectual capital and performance of pharmaceutical firms in India. Journal of Intellectual Capital. 2014;15(1):83-99. DOI: 10.1108/JIC-04-2013-0049

8. Ruckdeschel C. Intellectual capital: The new wealth of organizations by Thomas Stewart. Performance Improvement. 1998;37(7):56-59. DOI: 10.1002/pfi.4140370713

9. Bontis N., Chua Chong Keow W., Richardson S. Intellectual capital and business performance in Malaysian industries. Journal of Intellectual Capital. 2000;1(1):85-100. DOI: 10.1108/14691930010324188

10. Nazir M. I., Tan Y., Nazir M.R. Intellectual capital performance in the financial sector: Evidence from China, Hong Kong, and Taiwan. International Journal of Finance \& Economics. 2021;26(4):6089-6109. DOI: 10.1002/ijfe. 2110

11. Pulic A. VAIC ${ }^{\mathrm{TM}}$ an accounting tool for IC management. International Journal of Technology Management. 2000;20(5/6/7/8):702-714. DOI: 10.1504/IJTM.2000.002891

12. Maditinos D., Chatzoudes D., Tsairidis C., Theriou G. The impact of intellectual capital on firms' market value and financial performance. Journal of Intellectual Capital. 2011;12(1):132-151. DOI: 10.1108/14691931111097944

13. Firer S., Williams S.M. Intellectual capital and traditional measures of corporate performance. Journal of Intellectual Capital. 2003;4(3):348-360. DOI: 10.1108/14691930310487806

14. Abdulsalam F., Al-Qaheri H., Al-Khayyat R. The intellectual capital performance of KuwaitiBanks: An application of VAICTM1 model. iBusiness. 2011;3(1):88-96. DOI: 10.4236/ib.2011.31014

15. Gupta K., Goel S., Bhatia P. Intellectual capital and profitability: Evidence from Indian pharmaceutical sector. Vision: The Journal of Business Perspective. 2020;24(2):204-216. DOI: 10.1177/0972262920914108

16. Chizari M.H., Mehrjardi R.Z., Sadrabadi M.M., Mehrjardi F. K. The impact of intellectual capitals of pharmaceutical companies listed in Tehran Stock Exchange on their market performance. Procedia Economics and Finance. 2016;36:291-300. DOI: 10.1016/S 2212-5671(16)30040-5

17. Lv B., Han D. The relationship between intellectual capital and corporate performance in Chinese biopharmaceutical industry. SHS Web of Conferences. 2015;17:01024. DOI: 10.1051/shsconf/20151701024

18. Narwal K.P., Ramandeep. The relationship between intellectual capital and financial performance: An empirical study of Indian pharmaceutical industry. MERC Global's International Journal of Management. 2014;2(4):151-169. URL: https://www.academia.edu/30674661/The_Relationship_between_Intellectual_ Capital_and_Financial_Performance_An_Empirical_Study_of_Indian_Pharmaceutical_Industry

19. Kweh Q.L., Ting I.W.K., Hanh L. T.M., Zhang C. Intellectual capital, governmental presence, and firm performance of publicly listed companies in Malaysia. International Journal of Learning and Intellectual Capital. 2019;16(2):193-211. DOI: 10.1504/IJLIC.2019.098932 
20. Aslam S., Amin S. Impact of intellectual capital on financial vulnerability of pharmaceuticals sector in Pakistan. Pakistan Journal of Commerce and Social Sciences. 2015;9(1):171-184. URL: https://www. econstor.eu/bitstream/10419/188188/1/pjcss227.pdf

21. Xinyu Z. The impacts of intellectual capital of China's Public pharmaceutical company on company's performance. Journal of Chemical and Pharmaceutical Research. 2014;6(4):999-1004. URL: https://www. jocpr.com/articles/the-impacts-of-intellectual-capital-of-chinas-public-pharmaceutical-company-oncompanys-performance.pdf

22. Tandon K., Purohit H., Tandon D. Measuring intellectual capital and its impact on financial performance: Empirical evidence from CNX nifty companies. Global Business Review. 2016;17(4):980-997. DOI: 10.1177/0972150916645703

23. Bontis N. Intellectual capital: An exploratory study that develops measures and models. Management Decision. 1998;36(2):63-76. DOI: 10.1108/00251749810204142

24. Anifowose M., Abdul Rashid H.M., Annuar H.A., Ibrahim H. Intellectual capital efficiency and corporate book value: Evidence from Nigerian economy. Journal of Intellectual Capital. 2018;19(3):644-668. DOI: 10.1108/JIC-09-2016-0091

25. Ghosh S., Mondal A. Indian software and pharmaceutical sector IC and financial performance. Journal of Intellectual Capital. 2009;10(3):369-388. DOI: 10.1108/14691930910977798

26. Chowdhury L.A.M., Rana T., Azim M.I. Intellectual capital efficiency and organisational performance: In the context of the pharmaceutical industry in Bangladesh. Journal of Intellectual Capital. 2019;20(6):784806. DOI: $10.1108 /$ JIC-10-2018-0171

27. Pal K., Soriya S. IC performance of Indian pharmaceutical and textile industry. Journal of Intellectual Capital. 2012;13(1):120-137. DOI: 10.1108/14691931211196240

28. Engelman R. M., Fracasso E. M., Schmidt S., Zen A.C. Intellectual capital, absorptive capacity and product innovation. Management Decision. 2017;55(3):474-490. DOI: 10.1108/MD-05-2016-0315

29. Manes Rossi F., Nicolò G., Tartaglia Polcini P. New trends in intellectual capital reporting: Exploring online intellectual capital disclosure in Italian universities. Journal of Intellectual Capital. 2018;19(4):814-835. DOI: 10.1108/JIC-09-2017-0119

30. Pulic A. Intellectual capital - does it create or destroy value? Measuring Business Excellence. 2004;8(1):62-68. DOI: 10.1108/13683040410524757

31. Montequín V.R., Fernández F. O., Cabal V.A., Gutierrez N.R. An integrated framework for intellectual capital measurement and knowledge management implementation in small and medium-sized enterprises. Journal of Information Science. 2006;32(6):525-538. DOI: 10.1177/0165551506067127

32. Vidyarthi H., Tiwari R. Cost, revenue and profit efficiency characteristics, and intellectual capital in Indian banks. Journal of Intellectual Capital. 2020;21(1):1-22. DOI: 10.1108/JIC-05-2019-0107

33. Nazari J. A., Herremans I. M., Isaac R. G., Manassian A., Kline T. J. Organizational characteristics fostering intellectual capital in Canada and the Middle East. Journal of Intellectual Capital. 2009;10(1):135-148. DOI: $10.1108 / 14691930910922950$

34. Nadeem M., Gan C., Nguyen C. The Importance of intellectual capital for firm performance: Evidence from Australia. Australian Accounting Review. 2018;28(3):334-344. DOI: 10.1111/auar.12184

35. Greene W.H. Econometric analysis. $5^{\text {th }}$ ed. Upper Saddle River, NJ: Prentice-Hall, 2003. 1026 p.

36. Arellano M. On the testing of correlated effects with panel data. Journal of Econometrics. 1993;59(12):87-97. DOI: 10.1016/0304-4076(93)90040-C

37. Wooldridge J.M. Econometric analysis of cross section and panel data. Cambridge, MA, London: The MIT Press; $2002.741 \mathrm{p}$.

38. Xu J., Liu F. The impact of intellectual capital on firm performance: A modified and extended VAIC model. Journal of Competitiveness. 2020;12(1):161-176. DOI: 10.7441/joc.2020.01.10

39. Xu J., Wang B. Intellectual capital and financial performance of Chinese agricultural listed companies. Custos e Agronegocio. 2019;15(1):273-290.

40. Gujarati D. N., Porter D. C. Basic econometrics. $5^{\text {th }}$ ed. Boston, MA: McGraw-Hill/Irwin; 2009. 922 p.

41. Field A. Discovering statistics using IBM SPSS statistics: And sex and drugs and rock'n'roll. Los Angeles, CA: SAGE Publications; 2013. 915 p.

42. Hill R. C., Griffiths W.E., Lim G.C. Principles of econometrics. $4^{\text {th }}$ ed. New York: John Wiley \& Sons, Inc.; 2011.790 p. 


\section{ABOUT THE AUTHORS / ИНФОРМАЦИЯ ОБ АВТОРАХ}
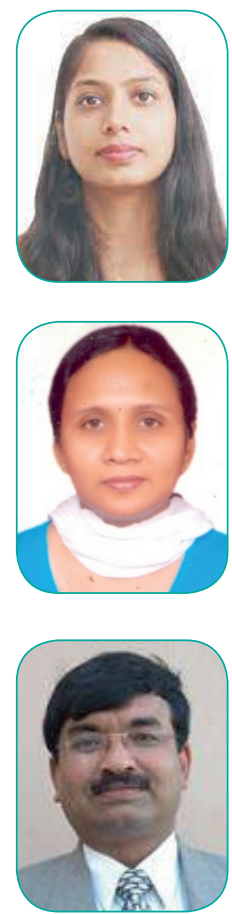

Soumya Singhal - Research Scholar, Amity College of Commerce and Finance, Amity University, Noida, India

Сумья Сингхал - научный сотрудник Колледжа торговли и финансов Амити, Университет Амити, Нойда, Индия

https://orcid.org/0000-0003-1861-3748

soumya_singhal@yahoo.com

Seema Gupta - PhD in finance, Professor, Amity College of Commerce and Finance, Amity University, Noida, Uttar Pradesh, India

Сима Гупта - доктор экономических наук, профессор Колледжа торговли и финансов Амити, Университет Амити, Нойда, Уттар-Прадеш, Индия

https://orcid.org/0000-0001-9862-5612

sgupta18@amity.edu

Vijay K. Gupta - PhD, Professor, Indian Institute of Management, Indore, Madhya Pradesh, India

Виджай Кумар Гупта - доктор экономических наук, профессор, Индийский институт менеджмента, Индор, Мадхья-Прадеш, Индия

https://orcid.org/0000-0001-6557-1697

vkgupta@iimidr.ac.in

\section{Author's declared contribution:}

Singhal S. - identified the problem, developed the framework, review of literature, collected data, performed analysis and concluded.

Gupta S. - discussed the research results and conclusions.

Gupta V.K. - discussed the analysis techniques.

\section{Заявленный вклад авторов:}

Сингхал C. - постановка проблемы, разработка концепции статьи, критический анализ литературы, сбор данных, анализ и формирование выводов исследования.

Гупта С. - обсуждение результатов и выводов исследования.

Гупта В.К. - обсуждение методов анализа.

Conflicts of Interest Statement: The authors have no conflicts of interest to declare.

Конфликт интересов: авторы заявляют об отсутствии конфликта интересов.

The article was submitted on 13.10.2021; revised on 27.10.2021 and accepted for publication on 17.12.2021. The authors read and approved the final version of the manuscript.

Статья поступила в редакцию 13.10.2021; после рецензирования 27.10.2021; принята к публикации 17.12.2021.

Авторы прочитали и одобрили окончательный вариант рукописи. 